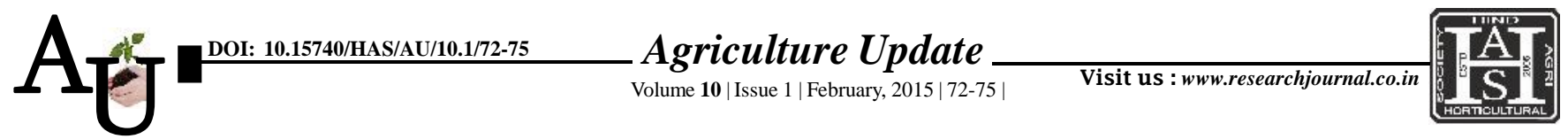

e ISSN-0976-6847

\title{
a Case Study: A comparative study on the performance of MGNREGA
}

SITARAM BISHNOI AND V.K. RAMPAL

Article Chronicle :

\section{Received :}

24.12.2014;

Accepted :

27.01.2015

\section{KeY WoRdS :}

MGNREGA, Women

beneficiaries,

Awareness,

Constraints,

Suggestions
SUMMARY : The MGNREGA, a self targeting programme, is intended in increasing outreach to poor and marginalized section of the society such as women and helping them towards the cause of financial and economic inclusion in the society. In this comparative study, an attempt has been made to analyze the performance of the MGNREGA in term of awareness of women beneficiaries about various provisions in MGNREGA and constraints faced by them while working under it. The study was conducted in Bikaner and Ludhiana districts of Rajasthan and Punjab, respectively. The sample consisted of 120 randomly selected respondents comprised of 60 women beneficiaries from each districts. Personal interview technique was used for collecting data. Findings of study show that respondents in both the districts are not much aware about the provisions under MGNREGA. Similarly, the respondents faced many problems while working under this Act regarding delay in issuing of job card, delay in payment, lack of crèche facility, harassment at work site etc. The study has made some suggestions also for incorporating improvement in the present MGNREGA scheme based on the constraints reported by the women beneficiaries associated with this act.

How to cite this article : Bishnoi, Sitaram and Rampal, V.K. (2015). A comparative study on the performance of MGNREGA. Agric. Update, 10(1): 72-75.
Author for correspondence :

\section{V.K. RAMPAL,}

Department of Extension

Education, Punjab

Agricultural University,

LUDHIANA (PUNJAB)

INDIA

See end of the article for authors' affiliations 